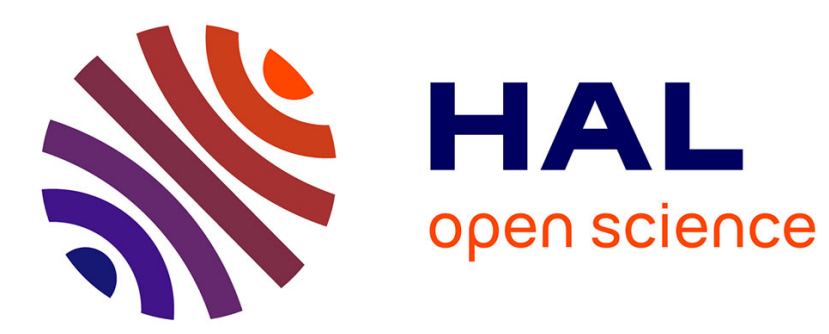

\title{
Optimization of the synthesis route of a barium boron aluminosilicate sealing glass for SOFC applications
}

\author{
Jean Puig, Andreas Prange, Baptiste Arati, Charles Laime, Pascal
}

Lenormand, Florence Ansart

\section{To cite this version:}

Jean Puig, Andreas Prange, Baptiste Arati, Charles Laime, Pascal Lenormand, et al.. Optimization of the synthesis route of a barium boron aluminosilicate sealing glass for SOFC applications. Ceramics International, 2017, 43 (13), pp.9753-9758. 10.1016/j.ceramint.2017.04.151 . hal-01757033

\section{HAL Id: hal-01757033 \\ https://hal.science/hal-01757033}

Submitted on 3 Apr 2018

HAL is a multi-disciplinary open access archive for the deposit and dissemination of scientific research documents, whether they are published or not. The documents may come from teaching and research institutions in France or abroad, or from public or private research centers.
L'archive ouverte pluridisciplinaire HAL, est destinée au dépôt et à la diffusion de documents scientifiques de niveau recherche, publiés ou non, émanant des établissements d'enseignement et de recherche français ou étrangers, des laboratoires publics ou privés. 


\section{Open Archive TOULOUSE Archive Ouverte (OATAO)}

OATAO is an open access repository that collects the work of Toulouse researchers and makes it freely available over the web where possible.

This is an author-deposited version published in : http:/oatao.univ-toulouse.fr/ Eprints ID : 19803

To link to this article : DOI:10.1016/j.ceramint.2017.04.151

URL : http://dx.doi.org/10.1016/j.ceramint.2017.04.151

To cite this version : Puig, Jean

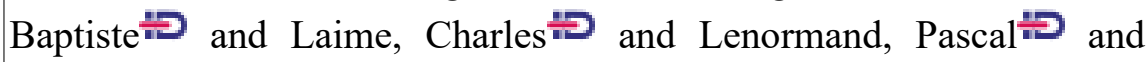
Ansart, Florence $\fallingdotseq$ Optimization of the synthesis route of a barium boron aluminosilicate sealing glass for SOFC applications. (2017) Ceramics International, vol. $43\left(\mathrm{n}^{\circ} 13\right)$. pp. 9753-9758. ISSN 02728842

Any correspondence concerning this service should be sent to the repository administrator: staff-oatao@listes-diff.inp-toulouse.fr 


\title{
Optimization of the synthesis route of a barium boron aluminosilicate sealing glass for SOFC applications
}

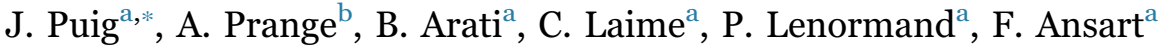 \\ a CIRIMAT, Université de Toulouse, CNRS, INPT, UPS, 118 Route de Narbonne, 31062 Toulouse cedex 9, France \\ b GHI, RWTH Aachen, Mauerstrasse 5, 52064 Aachen, Germany
}

\begin{abstract}
A B S T R A C T
A barium boron aluminosilicate sealing glass for IT-SOFC or SOFC applications was synthesized using different routes. Notably, sol-gel and solid state processes were used in order to obtain homogeneous glasses at 1100$1300{ }^{\circ} \mathrm{C}$. Sol-gel processes consist in a soft chemistry route allowing a better homogeneity between cationic precursors in the mixture and a better reactivity of the material. The influence of the process and of the glass processing temperature on the thermo-mechanical properties of the glasses were investigated after different heat treatments in air atmosphere, i.e. glass processing, sealing $\left(850^{\circ} \mathrm{C}-2 \mathrm{~h}\right)$ and ageing $\left(800{ }^{\circ} \mathrm{C}-100 \mathrm{~h}\right)$ procedures. It had been observed that the grain size of the glass powder (obtained after the glass processing and used for the sealing operation) is determining in order to manage the sealing procedure. Some large pores were formed during the devitrification step of the glass made by solid state route while glass sealants synthesized by the sol-gel route even at $1100{ }^{\circ} \mathrm{C}$ remained suitable for SOFC applications after thermal treatments, which proved that the sol-gel process is useful to decrease the glass processing temperature.
\end{abstract}

\section{Introduction}

SOFC or IT-SOFC (Intermediate Temperature Solid Oxide Fuel Cell) systems allow a direct conversion of chemical energy of a fuel into electrical energy and supplementary heat produced can be exploited. Stacks of individual cells connected in series have a great potential for power generation either in mobile or stationary applications and must work in the temperature range $500-1000^{\circ} \mathrm{C}[1,2]$. One of the challenges of this emerging conversion technology concerns the development of a sealant material ensuring the gas-tightness of cathodic and anodic compartments of the cells. The most important physicochemical properties of the sealant material are high temperature stability, electrical insulation $\left(10^{4} \Omega \mathrm{cm}\right)$, stable coefficient of thermal expansion (CTE) close to other cells components $\left(10-13 \cdot 10^{-6} \mathrm{~K}^{-1}\right)$, chemical inertia in reducing and oxidizing atmospheres and a sufficient plasticity at the joining temperature [3].

Various sealants materials have been investigated for this application, such as viscous and rigid glasses, glass-ceramics and cements $[4,5]$. Glass-ceramics are great candidates because they are flexible materials, i.e. a wide range of chemical compounds can be mixed in order to match with properties required for cells operation [4-7].

Among the glass-ceramics, a lot of investigations had been realized on barium boron aluminosilicate glass-ceramics due to the fact that these materials have CTE close to the CTE of the other cells components (steel interconnector and ceramic electrolyte) [8-17]. During the sealing process, a partial crystallization of the primary glasses occurs with the formation of various barium silicate crystals with high CTE varying from 9 to $17 \cdot 10^{-6} \mathrm{~K}^{-1}[4,8-10]$. Increasing $\mathrm{BaO}$ content and $\mathrm{B}_{2} \mathrm{O}_{3} / \mathrm{SiO}_{2}$ ratio in that glasses allowed an increase of the CTE [11]. The addition of $\mathrm{B}_{2} \mathrm{O}_{3}$ generally produces a decrease of viscosity, a delay in the crystallization step, which leads to a greater wettability of the glasses on cells components. Other phases can be promoted or inhibited with adding different chemical compounds. For instance, small additions of $\mathrm{CaO}, \mathrm{MgO}, \mathrm{Y}_{2} \mathrm{O}_{3}, \mathrm{La}_{2} \mathrm{O}_{3}$ and $\mathrm{ZrO}_{2}$ resulted in the formation of various crystals during devitrification process. Some of these crystals, like monocelsian $\mathrm{BaAl}_{2} \mathrm{Si}_{2} \mathrm{O}_{8}$, have a low CTE and could cause a decrease of the CTE of glasses leading to a CTE mismatch with other cell components $[4,10]$. Barium boron aluminosilicate G18 glass developed at PNNL (Pacific Northwest National Laboratory, USA) showed the presence of this phase after only $1 \mathrm{~h}$ at 750 or $850{ }^{\circ} \mathrm{C}$ and a decrease of the CTE of $15 \%$ after $168 \mathrm{~h}$ under SOFC operating conditions [12]. The effect of $\mathrm{Al}_{2} \mathrm{O}_{3}$ content in barium boron aluminosilicate glasses had also been investigated [13]. It had been proved that $\mathrm{Al}_{2} \mathrm{O}_{3}$ improves the crystallization temperature of these glasses but it promotes $\mathrm{BaAl}_{2} \mathrm{Si}_{2} \mathrm{O}_{8}$ formation since at least $2 \%$ $\mathrm{Al}_{2} \mathrm{O}_{3}$ are contained in the materials $[13,14]$. Another problem of the

\footnotetext{
* Correspondence to: PROMES-CNRS Laboratory, 7 Rue du Four Solaire, 66120 Font-Romeu, France.

E-mail address: jean.puig@promes.cnrs.fr (J. Puig).
} 
use of barium aluminosilicate glass-ceramics corresponds to the formation of $\mathrm{BaCrO}_{4}$ crystalline phase (high CTE potentially leading to cracks) at the interface between the glasses and the metallic interconnector [7,15-18]. However, promising performances had been obtained on short-term or on mid-term operations in air (up to $1500 \mathrm{~h}$ in dual atmosphere with no delamination [19]), in dual atmosphere (no delamination after $750 \mathrm{~h}$ [20]) or in real testing conditions with thermal cycles for SOFC applications [21].

In our previous works, we had developed a new sol-gel route to synthesize barium (boron) aluminosilicate glass sealants in order to process these glasses at a lower temperature than using a solid-state route and to improve the performance of these glasses for SOFC applications [22-26]. Indeed, many studies showed that the use of gel mixture could decrease the temperature of glass formation until $200 \mathrm{~K}$ below (possibly more) those required when using conventional batch material [27-29]. By this process, the reduction of the process temperature is possible due to a better homogeneity of the cationic salts mixture, which could induce better material properties and increase lifetime. At $1300{ }^{\circ} \mathrm{C}$, barium aluminosilicate glasses still contained crystals. With the adding of $\mathrm{B}_{2} \mathrm{O}_{3}, \mathrm{MgO}$ and/or $\mathrm{CaO}$, amorphous and homogeneous BBXAS $\left(\mathrm{BaO}-\mathrm{B}_{2} \mathrm{O}_{3}-\mathrm{Al}_{2} \mathrm{O}_{3}-\mathrm{SiO}_{2}\right.$ with $\mathrm{X}=\mathrm{CaO}$ and/or $\mathrm{MgO}$ ) glasses were obtained at the same temperature [22-24]. Four glass-ceramic sealants, with a $\mathrm{T}_{\mathrm{g}}$ between 596 and $626^{\circ} \mathrm{C}$, showed adequate electrical insulation after a sealing procedure and stable CTE and microstructure after sealing and ageing operation $\left(800^{\circ} \mathrm{C}-100 \mathrm{~h}\right)$ in air atmosphere. Furthermore, any reaction product at the steel interconnector-glass interface was observed and no hexacelsian or monocelsian crystals were identified in the formed glass-ceramic seals [24]. However, only the CM2 glass (chemical composition: $36 \% \mathrm{BaO}-2.6 \% \mathrm{Al}_{2} \mathrm{O}_{3}-10.3 \% \mathrm{~B}_{2} \mathrm{O}_{3}-10.3 \% \mathrm{MgO}-10.3 \%$ $\mathrm{CaO}-30.7 \% \mathrm{SiO}_{2}$ ) allowed preserving the gas-tightness of steel-glasssteel assemblies thermally treated at $700{ }^{\circ} \mathrm{C}$ or at $800{ }^{\circ} \mathrm{C}$ during $1000 \mathrm{~h}$ in air and in $\mathrm{H}_{2} / \mathrm{H}_{2} \mathrm{O}$ atmospheres [25,26]. Using CM2 glass as sealant material, a promising stable electrical performance of a commercial SOFC was obtained (low reduction of the open circuit voltage) during $\sim 2000 \mathrm{~h}$ at $800{ }^{\circ} \mathrm{C}$ under operating conditions with methane as fuel in cathodic compartment [30].

In this study, glasses with similar chemical composition of CM2 material were synthesized using sol-gel and solid-state processes at $1300{ }^{\circ} \mathrm{C}$ in order to confirm the benefits of the sol-gel process (lower processing temperature, better performance due to homogeneity).

After processing, the glasses were crushed into fine grains to form a glass paste to facilitate the sealing procedure. The influence of the grain size after glass processing by sol-gel route was observed in order to better the use of these glasses in SOFC applications. Finally, a glass had also been processed at $1100{ }^{\circ} \mathrm{C}$ in order to try to decrease the processing temperature. Thermo-physical properties of the glasses as-formed were evaluated. Microstructure and thermomechanical properties of the glass-ceramics after a sealing and an ageing procedure were investigated to determine the better synthesis procedure for an SOFC application at $700-800{ }^{\circ} \mathrm{C}$.

\section{Material and methods}

\subsection{Synthesis routes}

4 glasses with the same theoretical chemical composition of the promising CM2 material were prepared (Table 1). 3 glasses were synthesized using the sol-gel route previously described with a final processing heat treatment at $1300{ }^{\circ} \mathrm{C}$ during $3 \mathrm{~h}$ for SG1 and SG2 glasses and at $1100{ }^{\circ} \mathrm{C}$ during $1 \mathrm{~h}$ for SG3 glass [23,24]. Concerning the glass prepared by solid-state process, nearly-pure commercial powders $\mathrm{BaCO}_{3}, \mathrm{SiO}_{2}, \mathrm{MgO}, \mathrm{CaO}$ and $\mathrm{B}_{2} \mathrm{O}_{3}(325$ mesh, purity $>99,5 \%)$ were mixed together and heated at $1300{ }^{\circ} \mathrm{C}$ during $3 \mathrm{~h}$. In this case, $\mathrm{BaCO}_{3}$ powder was preferred to $\mathrm{BaO}$ powder to avoid any influence of residual impurities contained into $\mathrm{BaO}$ powders on the final glass chemical
Table 1

Description of the procedure fused to synthesize the glasses / glass powders.

\begin{tabular}{llll}
\hline Sample & Process & $\begin{array}{l}\text { Processing treatment } \\
\left({ }^{\circ} \mathbf{C}\right)\end{array}$ & $\begin{array}{l}\text { Grinding duration @ } \\
\mathbf{4 0 0} \mathbf{~ r p m}\end{array}$ \\
\hline SG1 & Sol-Gel & $1300-3 \mathrm{~h}$ & $5 \mathrm{~h}$ \\
SG2 & Sol-Gel & $1300-3 \mathrm{~h}$ & $15 \mathrm{~h}$ \\
SG3 & Sol-Gel & $1100-1 \mathrm{~h}$ & $15 \mathrm{~h}$ \\
SS1 & Solid-state & $1300-3 \mathrm{~h}$ & $15 \mathrm{~h}$ \\
\hline
\end{tabular}

composition and the glass properties. All the glasses were ground using a planetary mill (agate balls and cup) at $400 \mathrm{rpm}$ to obtain powders. Same grinding duration was used in order to obtain similar grain size except for SG1 glass (Table 1), which was already characterized in previous works $[24,26]$.

\subsection{Characterization methods}

After the glass processing and the grinding step, grains sizes were determined by a laser diffraction method, using a Beckman coulter LS particle size analyzer.

Thermo-physical properties of the glass powders were analyzed by using a Netzsch DSC 404. Scans were recorded from room temperature to $1100{ }^{\circ} \mathrm{C}$ at $10 \mathrm{~K} \mathrm{~min}^{-1}$. $\mathrm{T}_{\mathrm{g}}$ (transition temperature), $\mathrm{T}_{\mathrm{X}}$ (onset crystallization temperature) and $\mathrm{T}_{\mathrm{C}}$ (maximum crystallization temperature) of each glass were recorded (errors $\pm 5^{\circ} \mathrm{C}$ ).

Hot-stage microscopy measurements (HSM) were performed using a Hesse Instrument EMI1 equipment, which is composed of a CCD camera and a heat controlled furnace. Each glass powder was pressed into a pellet $(\sim 3 \mathrm{~mm}$ thick $\times 3 \mathrm{~mm} \varnothing)$ and samples were heated at $10 \mathrm{~K} \mathrm{~min}^{-1}$ from room temperature to $1100{ }^{\circ} \mathrm{C}$ on standard platinum substrate. According to the norm DIN 51730 1998-04 (Testing of solid fuels - Determination of fusibility of fuel ash), sample morphologies and contact angles were determined by a computer program to calculate, $\mathrm{T}_{\mathrm{S}}$ (softening), $\mathrm{T}_{\mathrm{SP}}$ (spherical), $\mathrm{T}_{\mathrm{HB}}$ (half-ball) and $\mathrm{T}_{\mathrm{F}}$ (flow) of glass sample. Three pellets of each glass were analyzed in order to have a representative average of the results.

In order to investigate the evolution of crystalline phases and of the thermomechanical properties after thermal treatments, each glass powder was pressed into pellets $(\sim 2 \mathrm{~mm}$ thick $\times 6 \mathrm{~mm} \varnothing)$. These pellets were heated during $2 \mathrm{~h}$ at $850{ }^{\circ} \mathrm{C}$ (heating rate $2 \mathrm{~K} \mathrm{~min}^{-1}$ ) in order to simulate sealing conditions. After this treatment, some of these pellets were also heated (heating rate $2 \mathrm{~K} \mathrm{~min}^{-1}$ ) during $10 \mathrm{~h}$ at $800^{\circ} \mathrm{C}$ to simulate SOFC operating conditions (also called "ageing”). The crystalline structure of glass-ceramic pellets was analyzed using XRD (X-Ray Diffraction) technique after each thermal treatment. XRD equipment was a Brucker AXS D4 Endeavor. Scans were recorded between $10^{\circ}$ and $100^{\circ}$ operating in Bragg-Brentano $(\theta-2 \theta)$ mode. Measurements of CTE as a function of temperature were carried out on glass pellets before and after thermal treatments using a dilatometer with a sensor Setsys Evolution TMA. CTE values were calculated from $200^{\circ} \mathrm{C}$ to $550{ }^{\circ} \mathrm{C}$ under air atmosphere; three pellets of each glass were characterized. Relative errors of the calculations were in the range $\pm 10 \%$. Scans were recorded from room temperature to $1100{ }^{\circ} \mathrm{C}$ at $10 \mathrm{~K} \mathrm{~min}^{-1}$. The samples were also analyzed using a SEM (Scanning Electron Microscope) model JEOL JSM 6700F.

\section{Results}

After the glass processing at 1100 or $1300{ }^{\circ} \mathrm{C}$, all the materials were amorphous. No diffraction pattern was detected using XRD (Fig. 1a), no crystals were observed and no phase separation was detected using SEM (Fig. 1b). So, all the glasses were homogeneous. Few other melting tests (not presented here) performed at lower temperature for glasses made with conventional or sol-gel routes, respectively at 


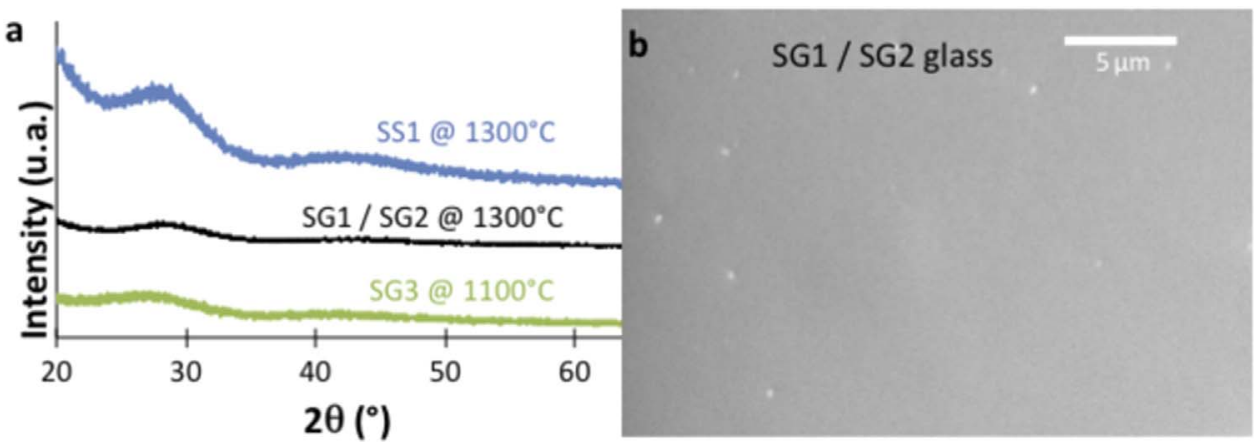

Fig. 1. a) XRD pattern of SS1, SG1/SG2 and SG3 glasses after glass processing, b) SEM image of SG1/SG2 glass.

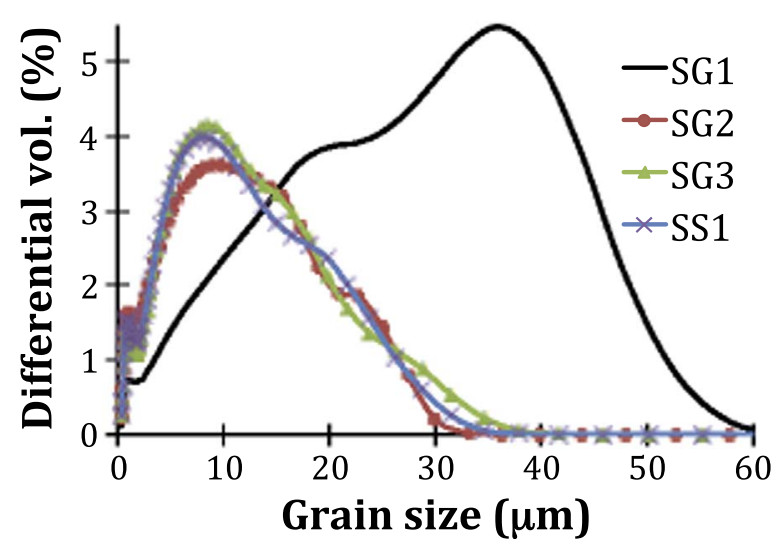

Fig. 2. Grain size distribution of the glasses after grinding operation.

$1100{ }^{\circ} \mathrm{C}$ or $1000^{\circ} \mathrm{C}$ showed that crystals were present in the formed glass leading to inhomogeneous systems. After the grinding operation, all the formed glass powders were polydisperse (Fig. 2). The median grain size in volume for SG2, SG3 and SS1 glasses was in the range 6$6.5 \mu \mathrm{m}$ with grains smaller than $40 \mu \mathrm{m}$. Although the median grain size for SG1 is higher $(17.5 \mu \mathrm{m})$, all the gains were smaller than $60 \mu \mathrm{m}$, which was suitable in order to seal SOFC components.

The $\mathrm{T}_{\mathrm{g}}$ and $\mathrm{T}_{\mathrm{x}}$ values of the four glasses are respectively close to $580-600{ }^{\circ} \mathrm{C}$ and $700-720^{\circ} \mathrm{C}$ (Table 2). Considering the error on the measurements $\left( \pm 5^{\circ} \mathrm{C}\right)$, the differences appeared negligible. On the other hand, $\mathrm{T}_{\mathrm{C}}$ of SG1 glass was $30-40^{\circ} \mathrm{C}$ higher than $\mathrm{T}_{\mathrm{C}}$ of other glasses, which proves that grain size has a little influence on the crystallization process.

The HSM software could not calculate $\mathrm{T}_{\mathrm{SP}}$ values for all the glass samples synthesized by sol-gel process. A hypothesis is that the formation of crystals may inhibit the evolution trough a spherical profile by mechanical strain. By contrast, temperatures $\mathrm{T}_{\mathrm{S}}, \mathrm{T}_{\mathrm{HB}}$ and $\mathrm{T}_{\mathrm{F}}$ were determined at a reasonable precision for all glasses $\left( \pm 5^{\circ} \mathrm{C}\right.$ except $\pm 10^{\circ} \mathrm{C}$ for SS1 glass) and were considered as more reliable data. The thermal behavior of the glass samples synthesized by solidstate process was different from the others during HSM experiments (Fig. 3). After an initial sintering from 610 to $670{ }^{\circ} \mathrm{C}$, an important increase of the volume, area and height of these samples occurred at $\sim 760{ }^{\circ} \mathrm{C}$ while the profile of the glass samples made by sol-gel process

Table 2

Characteristic temperatures of as-formed glasses using DSC and HSM.

\begin{tabular}{lcccccl}
\hline Sample & $\mathbf{T}_{\mathbf{g}}$ & $\mathbf{T}_{\mathbf{X}}$ & $\mathbf{T}_{\mathbf{C}}$ & $\mathbf{T}_{\mathbf{S}}$ & $\mathbf{T}_{\mathbf{H B}}$ & $\mathbf{T}_{\mathbf{F}}$ \\
\hline SG1 & 596 & 706 & 793 & 705 & 948 & 1012 \\
SG2 & 582 & 697 & 751 & 900 & 930 & 964 \\
SG3 & 577 & 719 & 752 & 902 & 962 & 1004 \\
SS1 & 600 & 716 & 763 & 786 & 901 & 971 \\
\hline
\end{tabular}

was not really changed. Above $890{ }^{\circ} \mathrm{C}$, all the glass samples had again a similar profile (from $\mathrm{T}_{\mathrm{HB}}$ to $\mathrm{T}_{\mathrm{F}}$ ).

$\mathrm{T}_{\mathrm{S}}$ of SG1 glass was nearly $200{ }^{\circ} \mathrm{C}$ lower than $\mathrm{T}_{\mathrm{S}}$ of SG2 and SG3 glasses. So, the smaller grain sizes of SG2 and SG3 glass samples have an important effect on the thermal behavior of the sample above $\mathrm{T}_{\mathrm{g}}$. It is supposed that a greater specific energy of these powders increases the crystallization rate close to $700{ }^{\circ} \mathrm{C}$ (in particular at the surface), which preserves the profile of the glass samples during heating in HSM experiments and delay the softening. $\mathrm{T}_{\mathrm{S}}$ of the sample synthesized by solid state route strongly depends on the brutal increase of the volume of the glass samples during heating procedure and could not be compared to $\mathrm{T}_{\mathrm{S}}$ obtained for the other glasses.

$\mathrm{T}_{\mathrm{HB}}$ of sol-gel glasses are generally high because of the probable accelerated formation of crystals, which slows the deformation of glass samples during heat treatment (Table 2). Changes in initial grain sizes and temperature processing appeared to have a weaker impact on $\mathrm{T}_{\mathrm{HB}}$, which could be explained. The formed crystals begin to melt at the same temperature in glass samples. $\mathrm{T}_{\mathrm{HB}}$ of the SS1 glass is lower than those of the other glasses. In fact, during the heating from 770 to $900{ }^{\circ} \mathrm{C}$, crystallization kinetics had probably been slowed by the energy released in the strong increase of the samples volume.

After the heat treatment of glass pellets at $850^{\circ} \mathrm{C}$ during $2 \mathrm{~h}$ simulating a sealing operation, the profile of the formed glass-ceramics issued from the sol-gel process remained similar (Fig. 4b-d). By contrast, the formed glass-ceramics issued from SS1 glass were more voluminous with the presence of large pores (Fig. 4e and f).

$\mathrm{XRD}$ technique was used to identify the crystalline phases in the four materials (Fig. 5). The same crystalline phases were formed in glass-ceramics with nearly similar diffraction pattern. A monoclinic $\mathrm{Ba}_{2} \mathrm{MgSi}_{2} \mathrm{O}_{7}$ phase, whose crystal structure has been recently reported, (calculated by Rietveld analysis assuming that $\mathrm{Ba}_{2} \mathrm{MgSi}_{2} \mathrm{O}_{7}$ was isostructural to $\mathrm{Ba}_{2} \mathrm{CoSi}_{2} \mathrm{O}_{7}$ ) is the major phase $[10,31]$. According to the PDF (Powder diffraction files) from ICCD (International Centre for Diffraction Data), further diffraction peaks could also be attributed to $\mathrm{MgSiO}_{3}$, several barium calcium silicates or barium silicates, which could be present as minor phases (diffraction pattern of some of these phases are very similar to the monoclinic $\mathrm{Ba}_{2} \mathrm{MgSi}_{2} \mathrm{O}_{7}$ pattern).

Various crystals were present and microstructural observations allowed to confirm it (Fig. 6). These crystals were generally anisotropic with edges in the range $1-10 \mu \mathrm{m}$ in the formed glass-ceramics (the crystals size was slightly higher in SG2 glass-ceramic than SG1 and SG3 materials). Other characterization techniques (EDX, TEM...) could be used in future experiments in order to be more precise on the structure of all the formed crystals and to accurately evaluate the amount of residual glass.

Some crystals of hexacelsian $\mathrm{BaAl}_{2} \mathrm{Si}_{2} \mathrm{O}_{8}$ phase could be present (traces) in SG1, SG3 and SS1 glasses due to the fact that some major diffraction peaks of this pattern $\left(22,48^{\circ}, 30,08^{\circ}, 33,82^{\circ}\right.$ and $40,99^{\circ}$ from the PDF 01-088-1048) match with obtained diffraction data. However, any fine dark needles representing these crystals were observed on the micrographs (Fig. 6c). The presence of large pores is 
$20^{\circ} \mathrm{C}$
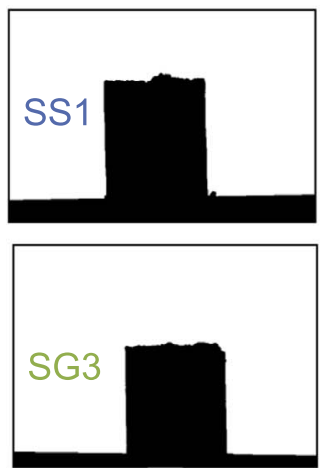

$\sim 700-720^{\circ} \mathrm{C}$

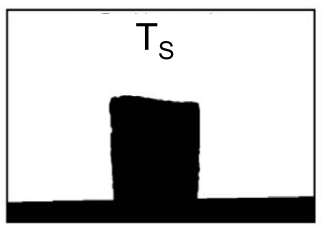

$\mathrm{T}_{\mathrm{S}}$
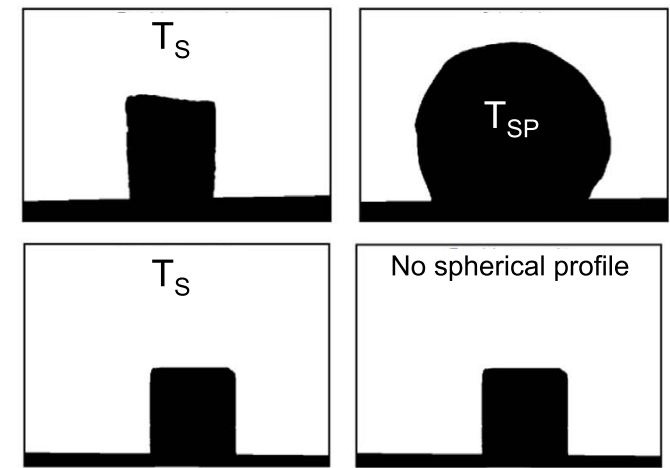

$900^{\circ} \mathrm{C}<\mathrm{T}<960^{\circ} \mathrm{C}$
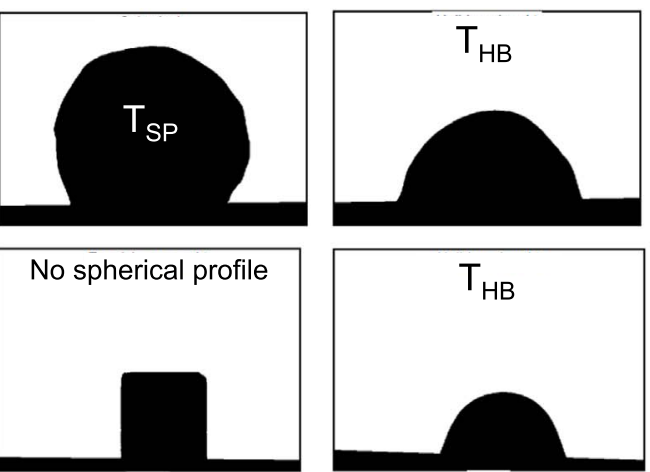

$>960^{\circ} \mathrm{C}$

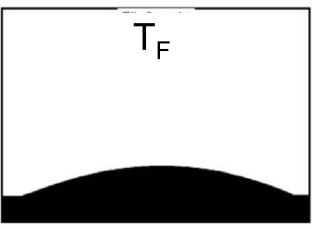

$\mathrm{T}_{\mathrm{F}}$

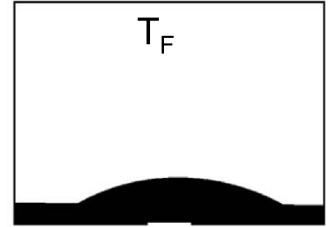

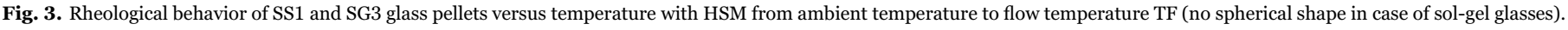

undesired in sealing process for SOFC applications due to the fact that it will degrade the electrical performances of the cells. So, supplementary investigations (ageing treatment and structural observations) were not realized on SS1 glass. For the glasses made by sol-gel route, the diffraction patterns obtained after an ageing treatment of $100 \mathrm{~h}$ at $800{ }^{\circ} \mathrm{C}$ were almost the same (Fig. 7), which proved the glass-ceramics obtained after the sealing treatment were already stable versus high temperature treatments.

The measured CTE of the as-formed glasses were in the range of 10 . $10^{-6} \mathrm{~K}^{-1}-13 \cdot 10^{-6} \mathrm{~K}^{-1}$ (Fig. 8). CTE of sol-gel glasses were very close from $12.3 \cdot 10^{-6} \mathrm{~K}^{-1}$ to $12.9 \cdot 10^{-6} \mathrm{~K}^{-1}$ while CTE of SS1 glass was lower. After a heat treatment at $850{ }^{\circ} \mathrm{C}$ during $2 \mathrm{~h}$ (simulation of a sealing procedure), CTE of glass-ceramics were in the range 10.9-11.9. $10^{-6} \mathrm{~K}^{-1}$. However, the error on the CTE measurement of SS1 glassceramic was bigger than $\pm 1.10^{-6} \mathrm{~K}^{-1}$ ( $>10 \%$ ) due to the big pores present in the samples.

Using an ageing treatment at $800{ }^{\circ} \mathrm{C}$ during $100 \mathrm{~h}$ on the same samples after the previous treatment, the CTE of the glasses synthesized by the sol-gel route stabilize around $10.9-11.2 \cdot 10^{-6} \mathrm{~K}^{-1}$.

\section{Discussion}

Considering SOFC applications at $700-800{ }^{\circ} \mathrm{C}$, the barium silicate glasses often have $\mathrm{T}_{\mathrm{g}}$ between $575{ }^{\circ} \mathrm{C}$ and $685^{\circ} \mathrm{C}[9,11,12,16]$. In this study, the low measured $\mathrm{T}_{\mathrm{g}}$ of the glasses are in the range $580-600^{\circ} \mathrm{C}$. In order to obtain a rigid seal with high mechanical properties, it is necessary to have strong devitrification in glasses and to avoid glass flow during the sealing operation. So, sealing temperature must be in the range $\left[\mathrm{T}_{\mathrm{C}}-\mathrm{T}_{\mathrm{HB}}\right]$ to satisfy these criterions. A pressure could be applied to facilitate joining procedure in case of a high contact angle. Considering these essential facts and the results issued from Table 2, it appeared possible to seal an SOFC with the proposed glasses at 800$900{ }^{\circ} \mathrm{C}$. The use of a heat treatment at $850{ }^{\circ} \mathrm{C}$ was perfectly adapted to simulate sealing conditions although only $800{ }^{\circ} \mathrm{C}$ could be use in future investigations in order to lower the thermomechanical constraints on other SOFC components. Concerning the ageing treatment, last promising results had already been obtained using SG1 or SG2 glasses at $700-800{ }^{\circ} \mathrm{C}$ in different atmospheres indicating that these glasses could be used at an intermediate temperature of $700{ }^{\circ} \mathrm{C}$ [24-26]. The ageing treatment at $800^{\circ} \mathrm{C}$ under air atmosphere chosen in this study was adequate to evaluate the synthesized glasses under more severe operating conditions.

Large pores were formed at temperatures over $760{ }^{\circ} \mathrm{C}$ in SS1 glass, which allow to reach a spherical shape at $\sim 850^{\circ} \mathrm{C}$ (Fig. 3). Furthermore, after $2 \mathrm{~h}$ at $850^{\circ} \mathrm{C}, \mathrm{SS} 1$ glass-ceramics remained very porous due to the fact that crystals maintained mechanical properties of the formed porosity (Fig. 4). Although SS1 glass appeared homogeneous after glass processing, $\mathrm{BaCO}_{3}$ could not have been fully decomposed because this compound generally decomposes into $\mathrm{BaO}$ and $\mathrm{CO}_{2}$ at temperatures close to $1300-1400{ }^{\circ} \mathrm{C}$. Furthermore, due to the reactivity of $\mathrm{BaCO}_{3}$ with $\mathrm{SiO}_{2}$ at low temperature, this compound could be decomposed at lower temperatures, which proves that the formed glass using solid-state route was not so homogeneous. So, the pores correspond to $\mathrm{CO}_{2}$ bubbles and it is necessary to use a higher glass processing temperature to ensure that $\mathrm{BaCO}_{3}$ is fully decomposed. Carbonates generally allow to obtain homogeneous glass at lower temperature and the use of another $\mathrm{BaO}$ precursor would not have similar effect or homogeneous glass could be obtained only at higher temperature.

In the case of sol-gel glasses, sintering and crystallization steps were considered as independent phenomena as no large pores were observed (Figs. 3 and 4). Considering that $\mathrm{T}_{\mathrm{X}}-\mathrm{T}_{\mathrm{g}}$ difference of SG3 glass is around $30^{\circ} \mathrm{C}$ higher than for the other glasses, this glass is more stable against crystallization process above $\mathrm{T}_{\mathrm{g}}$, which proved the adequate homogeneity obtained in this glass processed at the lower temperature $\left(1100^{\circ} \mathrm{C}\right)$. Although no calculations had been done on the crystallization rates, it appeared that these rates were higher in SG2 and SG3 glasses than in SG1 material as the measured $\mathrm{T}_{\mathrm{S}}$ were higher (Table 2). These glasses have been ground at a smaller grain size than SG1 material before the thermal analyses. So, a higher specific area was obtained and the glass reactivity over crystallization processes at high temperature was increased. This result demonstrates that the grain size a

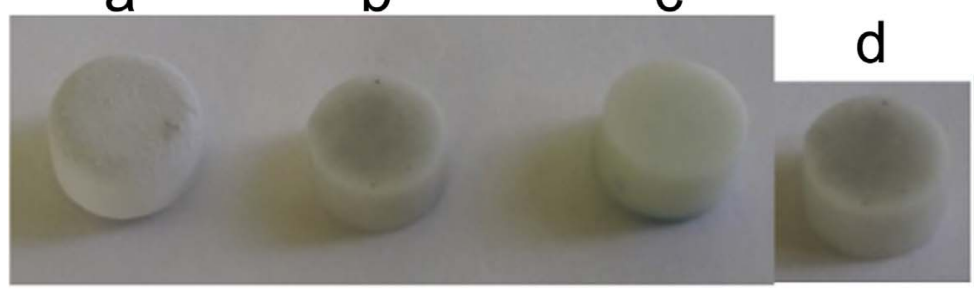

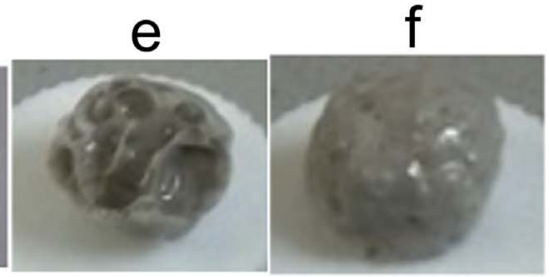

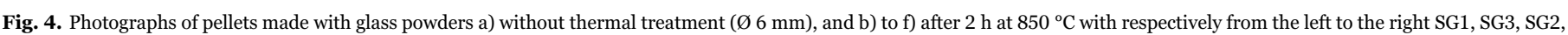
SS1 (bottom) and SS1 (top) pellets. 

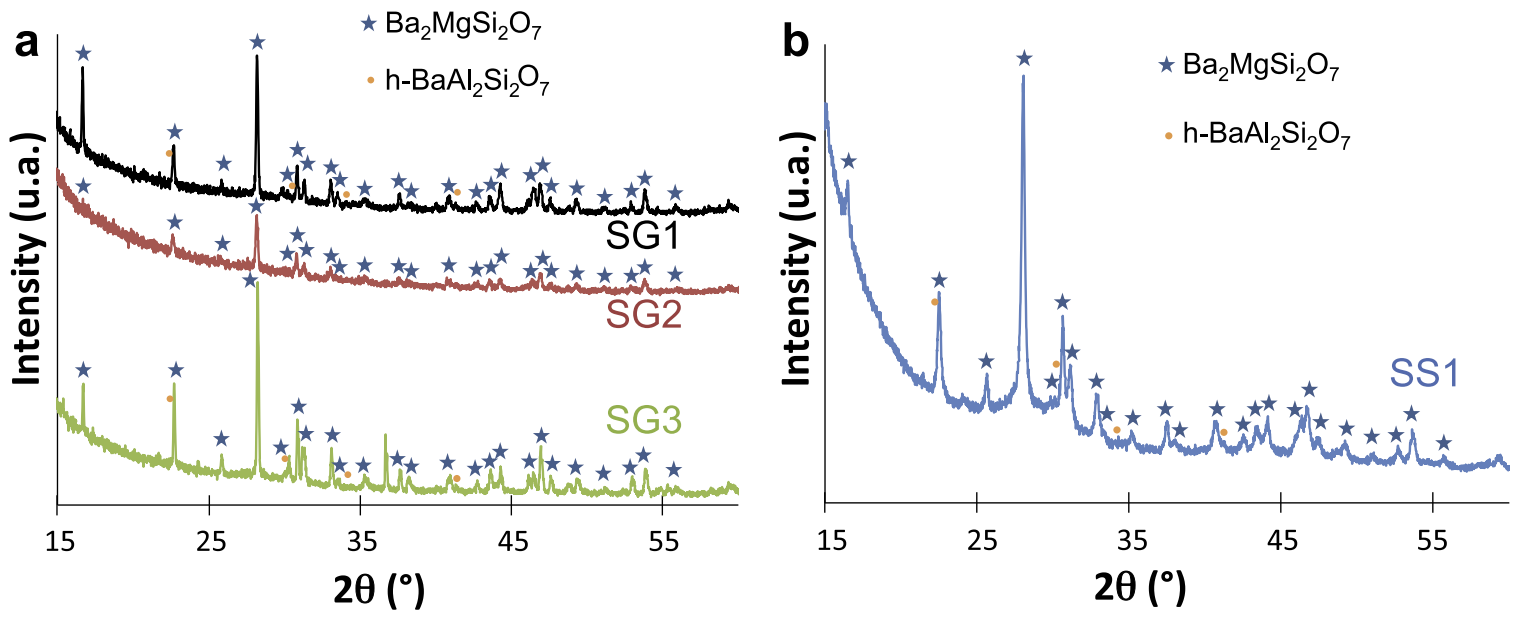

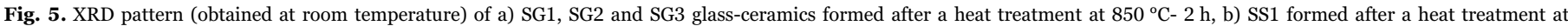
$850^{\circ} \mathrm{C}-2 \mathrm{~h}$.

of the glass powder obtained before the sealing operation (for all synthesis processes to make the glass) is very determining to select the right sealing temperature/process and will greatly participate to the success of the operation and to the long-term stability of the seal at high temperature.

Concerning the major identified crystalline phase, the CTE of monoclinic $\mathrm{Ba}_{2} \mathrm{MgSi}_{2} \mathrm{O}_{7}$ is around $8 \cdot 10^{-6} \mathrm{~K}^{-1}$ [10], which could explain the slight decrease of the CTE of sol-gel glass-ceramics during the first hours of devitrification at high temperature. However, barium calcium silicates and barium silicates with high CTE $\left(9-14 \cdot 10^{-6} \mathrm{~K}^{-1}\right)$ generally crystallize in BCAS glass [32]. The presence of these minor phases allowed to maintain the CTE of glass-ceramics at higher values close to $11-12 \cdot 10^{-6} \mathrm{~K}^{-1}$ (Fig. 8). According to literature, hexacelsian $\mathrm{BaAl}_{2} \mathrm{~S}_{\mathrm{i} 2} \mathrm{O}_{8}$ was present in several barium boron aluminosilicate glasses after thermal treatments of few hours at $800-900{ }^{\circ} \mathrm{C}$ and could transform over time at high temperature (100-200 h) into monocelsian phase, which could degrade their thermomechanical properties [10,32]. Presence of hexacelsian phase was suspected but microscopic observations did not prove it. Furthermore, no monocelsian phase $\mathrm{BaAl}_{2} \mathrm{~S}_{\mathrm{i} 2} \mathrm{O}_{8}$ was identified in the glass-ceramics after sealing and ageing operations. These phases could be absent due to the weak $\mathrm{Al}_{2} \mathrm{O}_{3}$ content in as-formed glasses and the formation of hexacelsian $\mathrm{BaAl}_{2} \mathrm{~S}_{\mathrm{i} 2} \mathrm{O}_{8}$ did not depend on the synthesis process in the present case.

The similar CTE values obtained after sealing and ageing treatments were expected due to:

- Similar chemical composition used in the sol-gel process,

- Similar crystalline phases identified in the materials with nearly similar crystals size,

- The amount of crystalline part, which appeared to be very close in the formed glass-ceramics as it had been observed on micrographs (Fig. 6).

CTE of materials synthesized using a sol-gel route is slightly

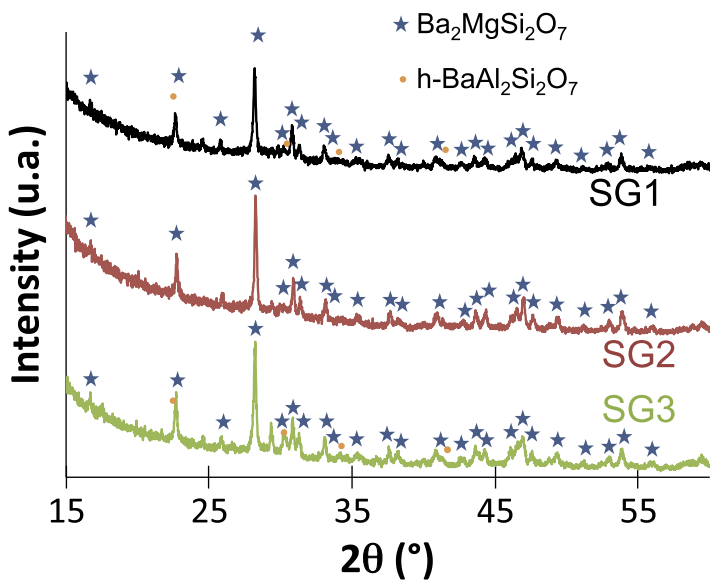

Fig. 7. XRD pattern (obtained at room temperature) of SG1, SG2 and SG3 glassceramics formed after a heat treatment at $800^{\circ} \mathrm{C}-10 \mathrm{~h}$.

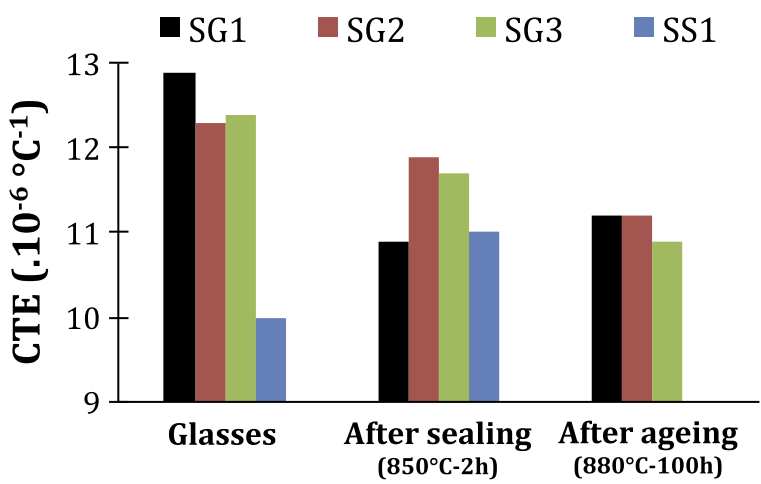

Fig. 8. Results of the CTE measurements from 200 to $550{ }^{\circ} \mathrm{C}$ after glass processing, sealing and ageing treatments.
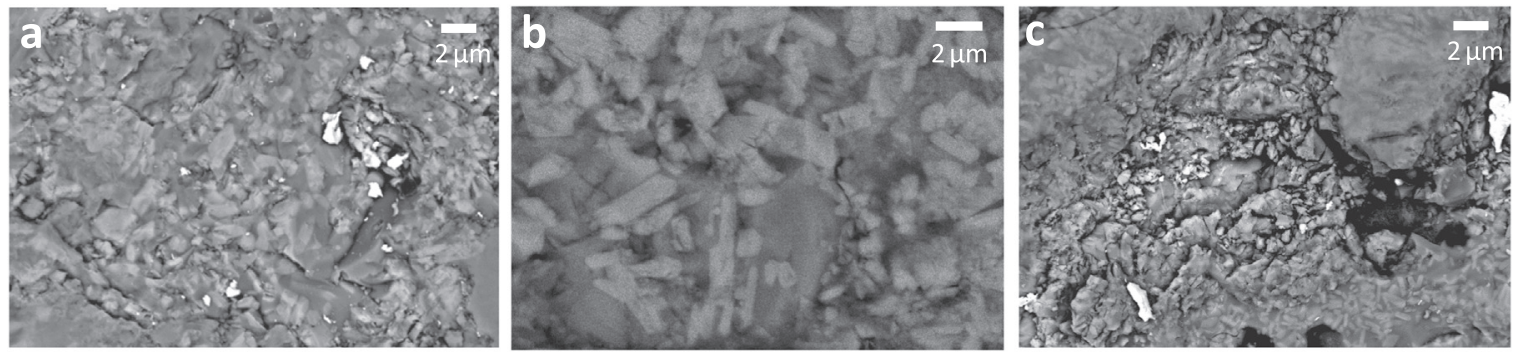

Fig. 6. Backscattered electron micrographs of glass-ceramics a) SG1, b) SG2, c) SG3 after $2 \mathrm{~h}$ at $850{ }^{\circ} \mathrm{C}$. 
increased or reduced after the ageing treatment of $100 \mathrm{~h}$ at $800^{\circ} \mathrm{C}$, which proved their good thermal stability. Therefore, stable thermomechanical and structural properties were well correlated, which argue positively on a long-term stability of the three sol-gel glasses. CTE of these glasses remained between CTE of common steel interconnector (notably K41x and CROFER22APU) and CTE of electrolyte (8-YSZ) after the heat treatments.

Considering all the results, it appeared that the processing temperature can be reduced at $1100{ }^{\circ} \mathrm{C}$ during $1 \mathrm{~h}$ for glasses synthesized by the sol-gel route (SG3), taking into account that sintering musts occur before crystallization step during the sealing process with a slow heating rate (close to $1-2 \mathrm{~K} \mathrm{~min}^{-1}$ ). As the grain size will influence the crystallization rate, the use of bigger glass grains with a median size in the range $10-20 \mu \mathrm{m}$ will allow to optimize the sealing procedure. Concerning SS1 glass synthesized by solid state route, the use of $1300{ }^{\circ} \mathrm{C}$ as final processing temperature is not adequate. It would be better to use directly $\mathrm{BaO}$ instead of $\mathrm{BaCO}_{3}$ in the initial mixture and to reach the melting around $1500-1600{ }^{\circ} \mathrm{C}$. Observing the obtained first results, this glass could have similar properties compared to sol-gel glasses but it must be confirmed by further investigations because metastable hexacelsian phase could be promoted with a different heating procedure. This process will need much more energy than the optimized sol-gel one at $1100^{\circ} \mathrm{C}$ due to the higher temperature involved.

\section{Conclusions}

Four amorphous barium boron aluminosilicate glasses with the same chemical composition were developed using different routes. Using similar conditions as in a sealing operation, the glass SS1 (solidstate route) was not adapted for an SOFC application due to the formation of large pores $\left(\mathrm{CO}_{2}\right.$ emissions during the decomposition of $\mathrm{BaCO}_{3}$ compound). So, the use of other precursor of $\mathrm{BaO}$ is necessary in the initial mixture in the solid-state route but it will increase the energy input involved in the final process in order to reach higher temperature. Taking into account the crystallization phenomenon into the glasses SG1, SG2 and SG3 during a sealing operation, it appeared that it is necessary to have a glass powder with grain sizes in the range $10-20 \mu \mathrm{m}$. A lower grain size will increase the glass stability over crystallization but it will also increase the crystallization rate when the temperature is in the range $\left[\mathrm{T}_{\mathrm{X}}-\mathrm{T}_{\mathrm{C}}\right]$ (SG2 and SG3 glasses). Monoclinic $\mathrm{Ba}_{2} \mathrm{MgSi}_{2} \mathrm{O}_{7}$ is the main crystalline phase formed during devitrification. Crystalline phases and microstructure of the formed glassceramics remained nearly similar after sealing procedure and after ageing treatment in air atmosphere, which proved that these materials are promising for a long-term operation at high temperature. Furthermore, the CTE of SG1, SG2 and SG3 glasses remained close to the CTEs of the steel interconnector and of the electrolyte, which indicates that these sealants were promising candidates for SOFC applications at $700-800^{\circ} \mathrm{C}$ (maybe also at $650{ }^{\circ} \mathrm{C}$ ). Finally, the use of a lower glass processing temperature at $1100^{\circ} \mathrm{C}$ (SG3) allowed to obtain similar homogeneity in glasses and glass-ceramics after devitrification at high temperature. So, the glass processing temperature for future investigations will be fixed at $1100{ }^{\circ} \mathrm{C}$, which is $400-500{ }^{\circ} \mathrm{C}$ below the glass processing for almost all glass seals used for this application.

\section{Acknowledgement}

Authors thank ADEME (Agence De l'Envivronnement et de la Maîtrise de l'Energie) and EIFER (European Institute For Energy Research) for their financial support. We would like to acknowledge K. Phillips from GHI (Aachen) for the DSC and HSM measurements and A. Pagès from the LMTG (Toulouse) for the grain size analyses.

\section{References}

[1] B.C.H. Steele, A. Heinzel, Materials for fuel-cell technologies, Nature 414 (2001) $345-352$.

[2] S.M. Haile, Fuel cell materials and components, Acta Mater. 51 (2003) 5981-6000.

[3] M.K. Mahapatra, K. Lu, Thermochemical compatibility of a seal glass with different solid oxide cell components, Int. J. Appl. Ceram. Technol. 7 (2010) 10-21.

[4] J.W. Fergus, Sealants for solid oxide fuel cells, J. Power Sources 147 (2005) 46-57.

[5] P.A. Lessing, A review of sealing technologies applicable to solid oxide electrolysis cells, J. Mater. Sci. 42 (2007) 3465-3476.

[6] M.K. Mahapatra, K. Lu, Seal glass for solid oxide fuel cells, J. Power Sources 195 (2010) 7129-7139.

[7] D.U. Tulyaganov, A. Amarnath Reddy, V.V. Kharton, J.M.F. Ferreira, Aluminosilicate-based sealants for SOFCs and other electrochemical applications a brief review, J. Power Sources 242 (2013) 486-502.

[8] M. Kerstan, C. Russel, Barium silicates as high thermal expansion seals for solid oxide fuel cells studied by HT-XRD, J. Power Sources 196 (2011) 7578-7584.

[9] A. Flugel, M.D. Dolan, A.K. Varshneya, Development of an improved devitrifiable fuel cell sealing glass I. Bulk properties, J. Electrochem. Soc. 154 (2007) B601-B608.

[10] M.D. Dolan, S.T. Misture, Development of an improved devitrifiable fuel cell sealing glass II. Crystallization behavior and structures of crystalline phases, J. Electrochem. Soc. 154 (2007) B700-B711.

[11] S.B. Sohn, S.Y. Choi, G.H. Kim, H.S. Song, G.D. Kim, Stable sealing glass for planar oxide fuel cell, J. Non-Cryst. Solids 297 (2002) 103-112.

[12] K.D. Meinhardt, D.S. Kim, Y.S. Chou, K.S. Weil, Synthesis and properties of a barium aluminosilicate solid oxide fuel cell glass-ceramic sealant, J. Power Sources 182 (2008) 188-196.

[13] T. Sun, H. Xiao, W. Guo, X. Hong, Effect of $\mathrm{Al}_{2} \mathrm{O}_{3}$ content on $\mathrm{BaO}-\mathrm{Al}_{2} \mathrm{O}_{3}-\mathrm{B}_{2} \mathrm{O}_{3}-$ $\mathrm{SiO}_{2}$ glass sealant for solid oxide fuel cell, Ceram. Int. 36 (2010) 821-826.

[14] M.J. Da Silva, J.F. Bartolomé, A.H. De Aza, S. Mello-Castanho, Glass-ceramic sealants belonging to BAS ternary system modified with $\mathrm{B} 2{ }_{0} 3$ addition: a different approach to access the SOFC seal issue, J. Eur. Ceram. Soc. 36 (2016) 631-644.

[15] A. Goel, D.U. Tulyaganov, V.V. Kharton, A.A. Yaremchenko, S. Eriksson, J.M.F. Ferreira, Optimization of $\mathrm{La}_{2} \mathrm{O}_{3}$-containing diopside based glass-ceramic sealants for fuel cell applications, J. Power Sources 189 (2009) 1032-1043.

[16] S. Ghosh, A.D. Sharma, A.K. Mukhopadhyay, P. Kundu, R.N. Basu, Effect of BaO addition on magnesium lanthanum alumino borosilicate-based glass-ceramic sealant for anode-supported solid oxide fuel cell, Int. J. Hydrog. Energy 35 (2010) $272-283$.

[17] Z. Yang, J.W. Stevenson, K.D. Meinhardt, Chemical interactions of bariumcalcium-aluminosilicate-based sealing glasses with oxidation resistant alloys, Solid State Ion. 160 (2003) 213-225.

[18] L. Peng, Q. Zhu, Thermal cycle stability of BaO-B2O3-SiO2 sealing glass, J. Power Sources 194 (2009) 880-885.

[19] S. Rodriguez-Lopez, V.A.C. Haanappel, A. Duran, F. Munoz, G.C. Mather, M.J. Pascual, S.M. Gross-Barsnick, Glass-ceramic seals in the system MgO-BaO$\mathrm{B}_{2} \mathrm{O}_{3}-\mathrm{SiO}_{2}$ operating under simulated SOFC conditions, Int. J. Hydrog. Energy 41 (2016) 15335-15345.

[20] G. Kaur, O.P. Pandey, K. Singh, Interfacial study between high temperature $\mathrm{SiO}_{2}$ $\mathrm{B}_{2} \mathrm{O}_{3}-\mathrm{AO}-\mathrm{La}_{2} \mathrm{O}_{3}(\mathrm{~A}=\mathrm{Sr}, \mathrm{Ba})$ glass seals and Crofer22APU for solid oxide fuel cell applications, Int. J. Hydrog. Energy 37 (2012) 6862-6874.

[21] L. Luo, Y. Lin, Z. Huang, Y. Wu, L. Sun, L. Cheng, J. Shi, Application of BaO-CaO$\mathrm{Al}_{2} \mathrm{O}_{3}-\mathrm{B}_{2} \mathrm{O}_{3}-\mathrm{SiO}_{2}$ glass-ceramic seals in large size planar IT-SOFC, Ceram. Int. 41 (2015) 9239-9243.

[22] J. Puig, F. Ansart, P. Lenormand, L. Antoine, J. Dailly, Sol-gel synthesis and characterization of barium (magnesium) aluminosilicate glass sealants for solid oxide fuel cells, J. Non-Cryst. Solids 357 (2011) 3490-3494.

[23] J. Dailly, M. Marrony, F. Ansart, J. Puig, P. Lenormand, Procédé de synthèse d'un verre de scellement par voie sol-gel, Patent EDF-CNRS, Europe EP2769962A1, 2014.

[24] J. Puig, F. Ansart, P. Lenormand, R. Conradt, S.M. Gross-Barsnick, Development of barium boron aluminosilicate glass sealants using a sol-gel route for solid oxide fuel cell applications, J. Mater. Sci. 51 (2) (2016) 979-988.

[25] J. Puig, F. Ansart, P. Lenormand, N. Bailly, S. Georges, J. Dailly, Barium borosilicate sealing glasses synthesized by a sol-gel process: chemical interactions with a stainless steel and gas-tightness of a SOFC, Fuel Cells 14 (6) (2014) 1014-1021.

[26] J. Puig, Development of Glass Seals Using a Sol-Gel Route in Order to Elaborate a Serial Repeat Unit for SOFC Applications (Thesis), University of Toulouse III, French, 2012.

[27] H.K. Tredway, S.H. Risbud, Gel synthesis of glass powders in the BaO-Al2_3_SiO2 system, J. Non-Cryst. Solids 100 (1988) 278-283.

[28] I. Lee, J. Covino, Sol-gel synthesis of monoclinic phase of barium aluminosilicate ceramics, Mater. Res. Bul. 29 (1994) 55-62.

[29] A. Makishima, T. Nagata, Application of the sol-gel process to lower the melting temperature of glaze, J. Non-Cryst. Solids 100 (1988) 519-522.

[30] S. Georges, N. Bailly, M.C. Steil, Y. Bultel, A. Hadjar, J.P. Viricelle, M. Rieu, SOFC long term operation in pure methane by gradual internal reforming, in: Proceedings of SOFC XIII Conference, Okinawa, October 6-11th, ECS Trans. 57, 2013, pp. 3023-3030.

[31] T. Aitasalo, J. Hölsa, T. Laamanen, M. Lastusaari, L. Lehto, J. Niittykoski, F. Pellé, Crystal structure of the monoclinic $\mathrm{Ba}_{2} \mathrm{MgSi}_{2} \mathrm{O}_{7}$ persistent luminescence material, Z. Krist. Suppl. 23 (2006) 481-486.

[32] N.P. Bansal, E.A. Gamble, Crystallization kinetics of a solid oxide fuel cell seal glass by differential thermal analysis, J. Power Sources 147 (2005) 107-115. 